\title{
O POPULAR, OS MEIOS E A DANÇA AXÉ NO INTERIOR DAS GERAIS
}

Rafael Guarato (Unicentro-PR)

Em tempos de virtualização das relações humanas, de supostas determinações econômica sobre a cultura, o artigo se propõe a divulgar considerações acerca das relações populares em tempos fluídos. Compreender as relações sociais, os valores contidos nos sucessos midiáticos entre as camadas populares, tomando como exemplo o interior de Minas Gerais e a dança Axé.

CULTURA POPULAR, MÍDIA, RELEITURAS, DANÇA. 
Em meio às culturas populares em áreas urbanas, a prática corporal apresenta-se como uma das principais características culturais. Com o intuito de não me alongar, focalizo a prática corporal da dança axé e seu recente boom na região do Triângulo Mineiro. Sem rodeios, para uma principiante compreensão dessa forma de dança, apresento distinções entre samba, pagode e axé, com base nas noções de seus

1. O presente texto divulga reflexões mais amplas abarcadas na dissertação de mestrado História e dança: um olhar sobre a cultura popular urbana, defendida em 2010 no Programa de Pós-Graduação em História da Universidade Federal de Uberlândia-MG.

praticantes. $^{1}$

Axé é saudação religiosa usada no candomblé e na umbanda que significa energia positiva. Sua extensão para designar prática musical se deu em finais da década de 1980 e início da seguinte. Sobre esse tema, Sílvio Essinger salienta:

Não se trata exatamente [de] um gênero ou movimento musical, mas [de] uma rotulação mercadológica muito útil para que uma série de artistas da cidade de Salvador, que faziam uma fusão de ritmos nordestinos, caribenhos e africanos com embalagem pop-rock, tomassem as paradas de sucessos do Brasil inteiro a partir de 1992 (ESSINGER, 2008).

Desse modo, a palavra axé não é usada para referir-se a uma prática corporal que entendemos como dança, mas sim para designar grupos musicais, segundo perspectiva mercadológica. A definição de grupos que fazem a fusão de ritmos apresentada por Essinger tornou-se amplamente praticável e utilizável pelos canto-

2. A princípio, o nome do grupo era Gera Samba e já existia desde o começo da década de 1980. Só no terceiro disco (1995), com a música "Segura o Tcham", o grupo conseguiu visibilidade nacional; suas músicas eram executadas "sem parar em todas as rádios, programas de TVs e festas por todo território nacional. A identificação por parte do público com a canção foi tão grande que o nome do disco acabou se tornando o nome do grupo." Informações obtidas em: Swingueira - $\mathrm{O}$ movimento que mais cresce no Brasil! Disponivel em: <http://www.sambando. com/swingueira9.htmls. Acesso em: 15 mar. 2009. res e grupos que a ela se dedicam. De acordo com Falcão, cantor da banda Guig Guetho: "é muito complicado, porque você não consegue vender pagode pra fora, você só vende como banda de axé" (VIRGínIA, 2007).

Contudo, o que os jovens e crianças uberlandenses praticam é uma musicalidade específica, no Estado da Bahia denominada "samba duro", porque "tem mais aceitação né cara, a galera gosta do som" (TORRES, 2008). O leitor reconhece tal musicalidade e prática dançante, associando-a ao grande ícone desse estilo: o grupo É o Tcham, ${ }^{2}$ que ganhou visibilidade com as apresentações de Carla Perez, Jacaré e Débora Brasil. Era o advento de dançarinos em banda de samba duro no âmbito nacional. Armindo Bião faz uma análise dessas performances de grande popularidade naquele momento, focando os grupos baianos Gera Samba e Companhia do Pagode, que se destacaram no Carnaval de 1996, se apresentaram em programas televisivos e fizeram muitos shows; suas músicas foram tocadas em rádios de todo Brasil e venderam milhares de cópias.

Todos os horários e todos os públicos da mídia brasileira têm assistido, quando não praticado, passos coreográficos que ressaltam o aspecto lúdico do ato sexual entre um homem e 
uma mulher, que pode resultar na geração de uma criança, ou simplesmente, entre uma pessoa e uma garrafa, que só resulta em ludicidade e excitação (BIÃo, 1998, p. 23).

É notável a distinção em nomenclaturas de formas musicais e dançantes oriundas do samba e reconfiguradas de maneiras diferenciadas em tempos e espaços diversos pelos populares em relação com o espaço midiático. Na Bahia, encontramos três concepções: a primeira usa as expressões samba raiz e/ou pagode paulista para classificar as produções de grupos e artistas como Alexandre Pires, Belo, Sorriso Maroto, Exaltasamba, Só Pra Contrariar e Molejo. A segunda forma de diferenciação é a dos grupos de samba duro, dentre os quais se destacam: Harmonia do Samba, Swingão, Psirico, Pagodart, As Meninas, Beto Jamaica, Companhia do Pagode, Fantasmão, Cafuné, Raghatoni, Nata do Samba, Oz Bambaz, Miskuta, Dignow, Primazia, Parangolé, Uns Kamaradas, O Rodo e Mi Usa. Por último, os grupos e artistas que são reconhecidos na Bahia como cantores de axé: Ivete Sangalo, Babado Novo, Claudinha Leite, Chiclete com Banana, Asa de Águia, Banda Eva, Cheiro de Amor, Jammil e Uma Noites, Margareth Menezes e Daniela Mercuri.

A ênfase deste texto recai sobre a prática dançante do samba duro. Assim, mesmo que em certos momentos seja utilizada a expressão dança axé, ela se refere ao samba duro. Trata-se de forma de dança em que o samba é utilizado como referencial primeiro, mas em cadência mais sincopada; as movimentações se centram nas regiões genitais e em gestos que aludem à sexualidade. Desde a expressão facial, em que boca, língua e olhos transmitem satisfação, perpassando tronco e quadril, que realizam movimentos em círculos, laterais e pendulares, vai-se criando um gestual envolvente, que remete à prática sexual num primeiro olhar.

A vinculação, quase inevitável, da prática dançante do samba duro às simulações de coito leva a juízos de valor precipitados, que findam por rotular tal dança como desprovida de significação, função social e conteúdo, restando-lhe os títulos de uma dança vulgar e carente de moral pública. Para além dessa constatação, o presente texto visa desvelar os significados atribuídos à dança axé pelos populares.

A existência de musicalidade e locais específicos para essa prática em Uberlândia coincide com a emergência do grupo baiano É o Tcham nos meios de comunicação de massa em meados da década de 1990. Foi quando grupos de samba da cidade incluíram, em seus repertórios, canções de samba duro. Mesmo antes da ascensão do grupo baiano, em Uberlândia havia grupos de samba e pagode como Só Pra Contrariar, Samba K, Tempero de Quintal, Flor do Samba e Frente a Frente, que se apresentavam em locais como Tribuna Livre, Coliseu, Black Chick, Pedágio Show e Skala Chop.

A existência e presença dessa cena de grupos de samba e pagode na cidade, que também se apresentam na região do Triângulo Mineiro, tornaram possíveis, aliás, a realização de programas de rádio e eventos periódicos, como o programa "Roda de Samba", transmitido pela Rádio Universitária e comandado pelo radialista Vítor Hugo de Oliveira, que organizava a famosa Kizomba, que no dialeto africano significa encontro de raças. Esses eventos, reunindo vários grupos de pagode, foram iniciados em 1989 e persistiram 
por mais de 12 anos; "às vezes somavam 10 a 12 grupos em um mesmo evento, na carroceria de um caminhão, no meio de uma rua, em algum lugar da periferia uberlandense. Nunca uma Kizomba reuniu menos de 1.500 pessoas" (OLIVEIRA, 1999, p. 18).

Outro fator que torna possível a identificação da crescente produção e do amplo consumo de canções do gênero samba e pagode é a aparição de artistas de renome nacional na Exposição Agropecuária de Uberlândia. Até 1992, quando começaram as negociações e shows no Camaru Agronegócios, toda a programação do evento era destinada ao público rural; era o momento "de abrir o baú, e apanhar lá o chapéu, botas, esporas, e tudo o mais que a fantasia de cada um permitir (...) quem não tem botas de couro legítimo vai de botinas" (CORREIO DO TRIÂNGULO, 1990, p. D-1).

A aparição do grupo musical Raça Negra, "um dos precursores do pagode român-

3. As edições da Exposição Agropecuária de Uberlândia já tinham inserido, em suas programações, shows com artistas de pop-rock nacionais, mas não com periodicidade fixa. Por exemplo, em 1989 participaram os grupos Roupa Nova e Dominó, e em 1990 esteve do evento o cantor Fábio Júnior; em 1994 novamente o grupo Roupa Nova, em 1999 Paralamas do Sucesso e em 2000 Jota Quest. Grupos de samba e pagode se fizeram mais presentes nesse evento de maior domínio de duplas sertanejas. Em 1993 os grupos Só Pra Contrariar e o Raça Negra se apresentaram, tendo este último retornado no ano seguinte. De 1995 a 2008, as edições anuais da festa contaram com o Grupo Molejo, novamente os grupos Só Pra Contrariar e Raça Negra, Katingulê, Exalta Samba, Bala, Bombom e Chocolate, Jorge Aragão, Alcione, tico ou 'samba paulista' como também é conhecido" (CORREIO DO TRIÂNGULO, 2001, p. D-1), na XXIX edição da festa agropecuária marcou o início da percepção, por parte dos organizadores do evento, de que havia em Uberlândia um significativo filão de consumidores que se identificavam com samba e pagode. Sintoma dessa constatação foi a constância, após 1992, de grupos de samba e pagode nas edições posteriores da festa. ${ }^{3}$

Essa cena cultural em torno de samba e pagode nas periferias da cidade possibilitou, aos populares, vivenciar a atividade corporal do samba duro, por intermédio dos meios de comunicação de massa que veiculavam danças de grupos como É o Tcham e Companhia do Pagode. Também contribui a reprodução de hits como "Boquinha da Garrafa" e "Segura o Tcham" por grupos e bandas locais em boates e festas na cidade em meados da década de 1990.

A circulação de músicas e danças de samba duro através dos meios de comunicação de massa foi tão intensa, que recebeu atenção de acadêmicos, a exemplo de Armindo Bião (1998, p. 24), que recorreu ao histórico da Bahia para afirmar que aquele estado possui um "dos piores quadros socioeconômicos do mundo" , numa tentativa de justificar a inserção de artistas populares baianos na mídia. Segundo o autor, a indústria cultural promove avanços na qualidade de vida e na afirmação da cidadania dos populares, abrindo "possibilidades de promoção social na Bahia, espetacularizando suas tradições culturais".

Também a professora e pesquisadora Márcia Strazzacappa (2001, p. 71), ao analisar como o corpo é tratado na escola, diagnostica a falta de incentivo à experimentação e movimentação corporal no ambiente escolar formal contem- 
porâneo no Brasil, ressaltando que o indivíduo interage com o mundo por meio de seu corpo:

se há alguns anos atrás, a primeira imagem que vinha à mente destes jovens era a figura da bailarina clássica nas pontas dos pés, hoje essa imagem (embora ainda muito presente) já está sendo substituída por outras trazidas pela mídia. As respostas variam entre dançarinas do "Tcham" e algumas pop stars norte-americanas (nota-se a predominância da figura feminina). ${ }^{4}$

Assim, não só Uberlândia, mas todo o Brasil teve acesso ao samba duro em meados da década de 1990. A presença e interferência de danças divulgadas na mídia sobre a cultura popular é algo intenso na contemporaneidade. Tal como a dança axé, a dança de rua e o hip hop no Brasil foram gestados no entremear de referenciais propagados massivamente, tanto em seus primeiros moldes como atualmente. ${ }^{5}$

A forte presença dessa dança baiana nos meios de comunicação de massa e sua exacerbada exibição e popularidade na sociedade brasileira fizeram retornar discussões que falam de bens culturais veiculados nos meios de comunicação de massa como algo desprovido de conteúdo artístico e de função social. Nessa perspectiva, a televisão, por exemplo, "se convierte en substitución de una inmediatez social a la cual los hombres hoy no tienen acceso" (ADORNO, 1969, p. 68). Segundo tal modo de perceber a prática dançante do samba duro nos meios massivos, sua forma de exibição, seus movimentos executados, suas vestimentas e indumentárias características estão fadados à sugestão explícita de prática sexual pura e simplesmente.

Num paralelo com o samba duro e para além da crítica à alusão e ao incentivo da prática do sexo, que colocam em jogo uma moral coletiva ao tornar público o privado, a dança axé também não desfruta de julgamento positivo no campo artístico da dança. Em seu recente texto intitulado "A diferença entre arte e cultura", a crítica, professora e pesquisadora de dança Helena Katz mostra a importância da arte no cotidiano e sua capacidade de "estimular os nossos sentidos de maneira especial". Tentando suavizar seu discurso, a autora reconhece a existência de diferentes formas de arte, como, por exemplo, a "arte popular", destacando que a não compreensão das artes provém do não acesso a elas. No entanto, peca ao afirmar que o acesso à arte é restrito, "pois as artes não estão, por exemplo, na televisão e nem
Fundo de Quintal, Swing e Simpatia, Grupo Revelação, Alexandre Pires, $D^{\prime}$ Corpo Inteiro e Skema Novo. Tais informações poderão ser encontradas em jornais locais, especificamente em: Programação oficial. Correio do Triângulo, 31 ago. 1991, p. C-1. Rural; XXIX Exposição Agropecuária de Uberlândia, Correio, 02 set. 1992, p. 9. Cidades; Camaru: Grupo Só Pra Contrariar é show de hoje, Correio do Triângulo, 29 ago. 1993, p. 17. Revista de Domingo; Programação da XXX Exposição Agropecuária de Uberlândia, Correio do Triângulo, 31 ago. 1993. p. A-8. Especial; Programação da XXXI Exposição Agropecuária de Uberlândia. Correio do Triângulo, 27 ago. 1994. p. 3. Política; Programação da XXXII Exposição Agropecuária de Uberlândia, Correio, 30 ago. 1995, p. 20. Rural; Programação do Camaru, Correio, 31 ago. 1996, p. 24. Especial; Programação do Camaru 97, Correio, 27 ago. 1997, p. 18. Rural; Programação Camaru - 1998, Correio, 28 ago. 1998, p. 24. Revista; Programação do Camaru 99, Correio, 26 ago. 1999, p. B-6. Esportes; Exposição será aberta amanhã, Correio, 30 ago. 2000, p. A-7. Economia; Programação da XXXVIII Exposição Agropecuária de Uberlândia, 
Correio, 30 ago. 2001. p. A-10; Naves, Janaína. Cardápio musical para todos os gostos, Correio, 29 ago. 2002, p. D-1. Revista; Moreira, Gustavo. Atração para todos os gostos no Camaru. Correio, 29 ago. 2003, p. C-3. Revista; Shows Camaru 2004. Correio, 29 ago. 2004, p. B-1. Cidade; Shows Camaru 2005, Correio, 27 ago. 2005, p. C-1. Revista; Shows, Correio, 26 ago. 2007, p. C-1. Revista; Shows no Camaru 2008, Correio, 29 ago. 2008, p. C-1. Revista.

4. Segundo a autora, a mídia fornece modelos o tempo todo. Entretanto, não se dedica ao aprofundamento dessa questão, sugerindo que esse modelo via mídia não ajuda muito; coloca-o apenas como algo que aparece. E centra seus esforços numa questão mais ampla, que é pensar formas para que os alunos tenham outras maneiras de experiência corporal; sugere que a escola formal seja local estratégico para isso.

5. Considerações mais detalhadas podem ser encontradas em Guarato, 2008.

6. As reflexões e os trechos citados se referem a Katz, 22 abr. 2009, p. 3. no rádio [permanecendo certa] desconfiança de que a arte não é para todo mundo". ${ }^{6}$

Dessa forma, surgem discursos que, longe de compreender a prática corporal do samba duro e suas significações no meio popular, fazem eclodir preconceitos carregados de juízos de valor, num panorama em que o popular é novamente o vilão. Preocupando-se com o ensino da dança, Maria Inês Galvão Souza percebe a interferência dos meios de comunicação de massa e da indústria cultural no aprendizado corporal de crianças e jovens brasileiros.

Basta lembrarmos das muitas "coreografias" que acompanham os produtos musicais por elas difundidos (coreografias de axé, de funk e dos grupos de pagode). Podemos até questionar a qualidade desses constructos (seu vocabulário corporal restrito e pobre, a ausência de liberdade de criação e expressão dos corpos, já que o público fica submetido à reprodução de certos modelos), mas não podemos negar a sua penetrabilidade, portanto, sua importância (souZA, 2004, p. 5).

Neste texto, Galvão é altamente tendenciosa; apresenta versão preconceituosa, historicamente instituída, que desloca as atenções para aspectos técnicos da prática popular massiva a fim de exercer exclusão social. Observações como "vocabulário corporal restrito e pobre" e "ausência de liberdade de criação e expressão dos corpos" colocam o público no lugar de receptor passivo que "fica submetido à reprodução de certos modelos". Essa análise não se esforça na compreensão dos modos de recepção e simbologia popular veiculada nos meios, muito menos considera as possibilidades de uso.

Esses recursos de linguagem, de grande impacto imagético, estão amplamente presentes no circuito da dança e na sociedade brasileira; tentam traçar a imagem do dançarino popular utilizando metáforas de inspiração sociológica, estética e biológica. ${ }^{7}$ Trata-se de procedimento de poder estético e ilustrativo de uma retórica de persuasão. São geradas imagens e discursos sobre esses dançarinos, identificando-os como emotivos, imitativos, adeptos de gestos feitos e de fácil aprendizado. O que se reforça é a noção de que "as opções culturais das camadas populares são muito menores" (souZA, 2004, p. 6).

Acerca de temática geradora de tantas controvérsias, as reflexões do literato inglês Raymond Williams me parecem dignas de nota. Ao historicizar o termo massa, o autor notou que tal nomenclatura surge acompanhada de outros con- 
ceitos, como "credulidade", "preconceitos de grupo", "vulgaridade de gosto e hábitos", com que se classificam as massas como ameaça à cultura "qualificada".

Embora massa fosse palavra nova para indicar multidão, populaça, conservava, em seu sentido, as características usualmente associadas ao vocábulo antigo: credulidade, volubilidade, preconceitos de grupo, vulgaridade de gosto e de hábitos. As massas, encaradas desse modo, constituíram perene ameaça para a cultura. Pensamento de massa, sugestão de massa, preconceito de massa, ameaçavam afogar o pensamento e o sentimento individual qualificado (WILLIAMS, 1969, p. 308).

Nesse sentido, se alguma forma de dança veiculada nos meios de comunicação de massa, como funk carioca, axé, forró, arroxa, dança de salão, ganhar algo, será a vitória da má dança, da vulgaridade e da mediocridade. Isso porque o sentido de massa é remetido ao outro. "Não considero massa meus parentes, amigos, vizinhos, colegas, conhecidos; nenhum de nós age ou pode agir assim. As massas são sempre os outros" (WILLIAMS, 1969, p. 309). Ou seja, não há massas; existem antes maneiras de ver os outros como massa. Segundo o autor, é preciso examinar o sentido que damos à massa e não a massa em si (p. 310). Assim, o problema central não é um trabalho ou forma de dança ter grande acesso e aceitação do público; o problema está nas ideias geradas a partir desses sucessos, ideias lançadas numa sociedade comandada por pessoas que renegam outras.

A ideia de massificação não pergunta às massas se elas querem ser massificadas, ela sintetiza a pluralidade. Na perspectiva analítica de Williams, o que é danoso para a sociedade não é a existência de eficientes e poderosos meios de transmissão múltipla, mas a ideia de massas e de comunicação de massa, que constitui modos de funcionamento de uma sociedade que "relega a maioria de seus membros à condição de populaça" (p. 314). Desse modo, o texto parte para perceber como ações corporais dançantes tidas como meros entretenimentos atuam na formação humana no meio urbano, caminhando contra a noção de que "o entretenimento sempre foi considerado como inferior ao esclarecimento, enquanto este se relaciona à arte superior burguesa, aquele sempre foi mais afeito à ingenuidade das manifestações populares e, por conseguinte, totalmente destituído de função esclarecedora" (SILVA, 2006, p. 27).

Fundamental é perceber, tal como fez Bauman, que a área de marketing investe em produzir consumidores para produtos que prometem aquilo de que eles precisam,
7. De diferentes formas e com referenciais distintos, Armindo Bião, Maria Inês Galvão Souza e Fabiana de Dultra Britto reforçam estereótipos acerca do fazer popular. Britto, com sua análise historiográfica em dança, limita o fazer popular ao "rígido", à "pouca flexibilidade". Galvão apresenta discurso menos complexo e reproduz juízos de valor já estabelecidos no "senso comum". Bião é o que lida de forma mais amistosa e analítica com o popular nos meios massivos, demonstrando que a indústria cultural possui seus lados positivos para os artistas populares, mas não acrescenta no que tange ao consumo desses bens veiculados pelos populares, muito menos seus processos de assimilação e apropriação. Para uma percepção dos diferentes modos de reprodução do processo excludente quanto aos mencionados fazeres populares em dança, consultar: Bião, 1998; Britto, 1999; e Souza, 2004. 
mas as necessidades formuladas pelo mercado não surgem no nada, elas partem de anseios e de desconfortos já sentidos (BAUMAN, 2006, p. 114 e 115). Entra em cena o processo de mediação, em que são alterados os sentidos dos produtos culturais de massa.

Nessa perspectiva, importa, mais do que controlá-las, investigar o que essas pessoas veem nos meios, o que pensam a partir do que viram. Essas brechas não acontecem nas mídias, mas no que as pessoas procuram e criam com suas expectativas sobre a mídia. A ideia de que a mídia forja expectativas, desejos, sentimentos e satisfação aos receptores não é desprovida de razão, mas também não é feita somente dela. Percebemos que ela não atua com tanto poder; certos fatores são assimilados, mas nunca da forma e

8. Entrevista Memória Roda Viva. Entrevistadores: Daniel Piza, Laio Leal, Maria Immacolata Vassalo de Lopes, Silvia Boreli, Lauro César Muniz, Eugênio Bucci, Roseli Fígaro e Gabriel Priolli. Disponivel em: <http:// www.rodaviva.fapesp. br/materia_busca/62/ mart\%EDn-barbero/ entrevistados/jesus. martinbarbero_2003. htm>. Acesso em: 19 nov. 2008. com o conteúdo que são propostos. Portanto, é "preciso entender que as pessoas não são idiotas" A televisão se tornou o lugar "onde elas se veem" (MARTín-BARBero) ${ }^{8}$. Assim, os meios são também proporcionadores de sonhos, enquanto a sociedade os desgasta. O que frustra expectativas não é a mídia, mas a realidade.

Ao mesmo tempo, os meios massivos veiculam o popular ou elementos que podem vir a se tornar populares (MARTín-BARBERO, 2003, p. 322), tal como ocorreu na dança de rua com movimentos oriundos de outras danças (jazz, funk e soul): alguns passos foram mantidos, mas com mudanças nos significados do se dançar, no modo de execução e nos lugares de exibição. O que impede o reconhecimento da atividade cultural são as transformações da experiência em produtos acabados.

O mercado, assim como muitos discursos midiáticos, considera as ações concluídas, tende a fixar formas, pressupõe relações, instituições e formações como definidas, não em transformação. Importa atentar para o fato de que o popular se destaca na cena brasileira da dança e em seu campo artístico uma vez que sofre alterações realizadas não por seus produtores, mas por outros, posto que está submetido a um processo artístico orientado por pessoas que detenham os códigos do como manipular os referenciais populares para transformá-los em arte degustável.

De todo modo, a prática corporal da dança axé, do samba duro especificamente, permaneceu circunscrita aos ambientes de festas, danceterias e eventos das cidades no interior das gerais, concentrando-se num fazer que só aparecesse nos finais de semana. Gilmar da Silva Ramos comenta que "na época as pessoas saíam muito mesmo pra se divertir num pagode, onde tocava axé, bandas tocava axé e divertia mesmo dançando ali"(RAMOS, 2009). Em meados de 2005, porém, o samba duro reapareceu na cena dançante, principalmente em Uberlândia, congregando, em poucos meses, centenas de adeptos que passaram a se organizar, a se relacionar coletivamente em torno dessa prática corporal no meio em que vivem. ${ }^{9}$ 
Embora já contando com as apresentações semanais de grupos musicais da cidade, com destaque para Kaçamba e D'Corpo Inteiro, que tocavam canções de samba e pagode em casas de show, como Ibiza, Coliseu, Chamego, Fuzuê, Zara Club, Rondon Beats, Happy Bear (Bar da Praia) e Point Music, só em 2002, com o retorno de Fábio Torres, ${ }^{10}$ conhecido como Mantena da Bahia, a dança axé ganhou fôlego e um ícone. Houve principalmente uma inovação referente aos corpos masculinos, pois, antes da aparição de Mantena, "quem rebolava era gay. Era só mulher que rebolava" (NASCIMENTO, 2009).

O retorno de Mantena para Uberlândia tornou-se marco para as camadas populares da cidade, principalmente para os jovens. Ele logo aceitou convite para fazer uma participação especial na gravação do DVD da banda D'Corpo Inteiro. ${ }^{11}$ Nesses ambientes de lazer, em que jovens se encontravam para curtir as noites ao som de samba, pagode e axé, começava um processo de formação de grupos de dança que se dedicavam ao aprendizado da dança axé e sua execução pública nos finais de semana. Festas, shows, boates e eventos em que se faziam presentes bandas locais que tocavam samba duro passaram a ser os espaços privilegiados nos quais os dançarinos exibiam seus passos e habilidades corporais em dança popular.

A princípio, esses coletivos de dançarinos eram formados por círculos de amigos, que já saíam juntos para dançar. Foi essa a primeira forma de organização coletiva em dança axé da cidade; antes, "na minha época não tinha nem aquele lance de grupinho de dança" (TORRES, 2008). A adesão à prática do samba duro, acompanhada da construção de significados atribuídos socialmente a essa dança pelos jovens das camadas populares, foi surpreendentemente forte e rápida, mas a abertura de espaços destinados a essa manifestação não seguiu ritmo igual. Gilmar da Silva Ramos, o Chumbinho, comenta que

aqui em Uberlândia o problema é o seguinte: não tem espaço, não tem nada. Muito das vezes os grupos de axé dança mesmo por dançar, por gostar. Então a gente vem com esse movimento aí, cada dia mais cresce né! Tendo lugar pra apresentar ou não, mais ta sempre crescendo, cada dia aparece um grupo diferente (RAMOS, 2009).
9. Até o momento da redação do presente texto havia registro de mais de 50 grupos de dança axé atuantes na cidade de Uberlândia. Na lista, os grupos Axé Delícia, Axé Minas, Axé Mix, Axé Street, Balança Axé, Balangandam, Billambond, Conexão Axé, Furacão Axé, Grupo Saravada, Kebraê, Kebra Rekebra, Kebradeira, Ki-Kebrança, Ki Swing, Opus6, Meninas Furacão, Parango Dance, Pegada Forte, Pegada Quente, Pervertidos do Axé, Pirei Axé, Pra Kebra, Quebradera Total, Raro Swing, Ritmos, Sensação do Axé, Spaço Axé, Stremesse, Swingão, Swingueto, Swing Contagia, Swing Axé, Swing ih Kebrança, Swing Loko, Swing de Rua, Swing do Gueto, Swing ki Delícia, Swing Kikebra, Swing Mania, Swing Mineiro, Swing Muleke, Swing Sensação, Swing Toda Boa, Swing Ragattoni, Taradas do Axé, Tentação do Axé e Tribo do Axé.

10. Fabio Torres teve seus primeiros contatos com a dança axé saindo nas casas noturnas e shows na cidade de Uberlândia por volta de 1997 e 1998. Foi à Bahia para aprender a dançar o axé, lá permanecendo quatro meses.

Todavia, para que a dança axé se tornasse um referencial, um modo de sociabilidade por meio da prática corporal, diversos significados atribuídos a sua prática começaram a ganhar força, tanto que congrega "hoje em torno de uns 60 a 70 grupos de dan- 
11. Apesar de as canções de autoria própria do grupo musical serem caracteristicamente de pagode paulista, a banda incluiu na gravação de seu DVD, entre as 23 músicas, dez de samba duro, tendo Mantena dançado em duas canções: "Smirnofy" e "Senta aqui". CF.: D"Corpo Inteiro: "eu sou mineiro" ao vivo. Uberlândia, 2005. DVD promocional. ça, eu imagino que seja isso" (TORRES, 2008). Mesmo sem a repercussão midiática que havia conquistado na década de 1990, o samba duro é hoje amplamente praticado em Uberlândia e região, sobretudo pela população jovem que "estuda e trabalha, a maioria" (NASCIMENTO, 2009), mas que não deixa de encontrar seus pares, de movimentar seus corpos e, principalmente, de manter relações amorosas, fraternas, amigáveis, econômicas e políticas por meio da dança.

São crianças e jovens que encontraram na prática corporal um meio de se relacionar em sociedade, de conhecer pessoas, de ser vistos e desejados. As concepções positivas construídas a respeito do samba duro geram satisfação em quem participa de grupos de dança axé: "é ótimo! Eu acho que faz parte da minha vida assim, eu gosto muito, todo dia ensaiar" (NAZARO, 2009). Outro sujeito que declara sua paixão pelo axé é Luiz Cesar Dias Nascimento, que iniciou seus estudos em dança contemporânea, em seguida fez aulas de teatro, mas "depois que eu vim pro axé, eu vivo muito do axé. Então é tão legal que é tudo envolvido no axé, é muito legal, é outro mundo eu conheço todo mundo que dança axé" (NASCIMENTO, 2009).

Neste momento, a intenção é captar a importância atribuída à prática dançante pelos populares, para que possamos ter noção da abrangência que tem em suas vidas, dando voz a quem declara que "sem o axé eu não existiria" e também àqueles que chegam a "fazer até trambique pra poder apresentar" (AZEVEDo, 2003). Nesses casos, a dança assume papel central na vida de seus praticantes. Não se trata de apenas constatar que "o lazer nas sociedades modernas passa a representar a 'válvula de escape' das tensões que se acumulam no processo de trabalho ou das frustrações e exclusões que se originam da falta dele" (DIÓGENES, 2001, p. 46), mas também de investigar como as tensões, frustrações e exclusões vivenciadas cotidianamente são superadas por meios outros de identificação coletiva.

Nesses grupos, a movimentação corporal característica da dança axé talvez seja o exemplo mais gritante, na contemporaneidade brasileira, de algo semelhante ao que Bakhtin (1993) constatou acerca da cultura popular na Idade Média, quando se configurava e se definia uma concepção do corpo que se opõe ao sério, ao controle oficial, culminando em formas de exclusão e não aceitação social de determinados fazeres. Pode-se tomar como exemplo esta declaração: "o pagode da Bahia foi por muito tempo censurado. Era visto como um tipo de música 'escandalosa', 'indecente', que exaltava o corpo e a sensualidade de uma forma vulgar" (ARAúso, s/d).

Muito mais do que a reunião de corpos em exibição e gestos insinuantes, a dança comporta significações elaboradas socialmente, que vão além da simples visualização e do vínculo a estereótipos. Mas, mesmo assim, lidam com "as regras do decoro, da civilidade, das boas maneiras ou da disciplina pedagógica" que buscam "conter os corpos 
instáveis, contraditórios e agitados de paixões ou de 'impulsos desordenados'" (CERTEAU, 2002 , p. 411). Estamos falando de corpos que rompem os limites da coerção social, mas nem por isso deixam de ser produzidos historicamente.

Acréscimo importante ao gestual é o figurino. No axé, as roupas são aquelas comumente usadas em regiões litorâneas do Nordeste, cuja temperatura elevada e a frequência à praia são fatores que contribuem para a redução no volume de tecidos nas peças do vestuário. Assim, não é de estranhar o uso de shorts curto e top ou blusas pequenas nos corpos femininos e shorts curtos, calções de banho e camisetas cavadas nos corpos masculinos. As roupas ganham outros significados no momento da dança, do corpo em ação cênica, com movimentos e gestos que chamam a atenção para as regiões genitais.

Como Uberlândia não apresenta aspectos naturais semelhantes aos das regiões litorâneas mencionadas, mas lida com todo o aparato social de coerção, os dançarinos de axé do interior das Gerais percebem que "aqui em Uberlândia o povo tem muito preconceito em relação à roupa" (AZEVEDo, 2003). Importa considerar que o que faz a dança ser "obscena" não é a vestimenta. A atenção se volta para os movimentos e não para o corpo, pois "é a partir da relação do objeto com o corpo na dança que é possível compreender o consumo do bem entre os membros do grupo". ${ }^{12}$

Os dançarinos sentem cotidianamente a coerção social que, de acordo com Gómez (2002), faz parte de um processo de urbanidade na América Latina, no qual a higiene e a medicina dirigem seu foco sobre o corpo, para o qual se estabelecem pressupostos de uso. O corpo é visto como algo que possui certas qualidades materiais. Essa visão limitada supõe que o corpo pode ser civilizado e assimilar um modo específico de se comportar. A meta é o cidadão civilizado, feliz e próspero. Isso equi12. Tal constatação foi feita pela pesquisadora Mizrahi acerca do figurino utilizado pelas dançarinas de funk na cidade do Rio de Janeiro. Mais informações em: Mizrahi, 2006. p. 207.

13. A realização de uma frase se refere a modulações no ritmo, como uma duplicação de notas, por exemplo. É similar ao que conhecemos como contratempo utilizado em dança.

vale a dizer que o corpo foi historicamente higienizado e modelado para se comportar em sociedade. É contra essa civilidade que se rebelam movimentos e vestimentas da dança axé.

A formação de grupos de dança que se dedicam à prática do samba duro inclui a construção, pelos populares, de significados estético-formais que compõem uma espécie de codificação de suas práticas, com o intuito de distinguir aqueles que mais se destacam, de acordo com valores por eles mesmos elaborados. Aspecto a relevar foi percebido por Lilian Vilela em seu estudo sobre o break e o funk miami, que é a "subordinação da dança em relação à música" (VILELA, 1998, p. 68). No samba duro, os instrumentos musicais percussivos dão sustentação ao ritmo desejado, levando os dançarinos a executar seus movimentos e gestos de acordo com a musicalidade executada, com o cuidado de atender às "frases"13 enunciadas pelos músicos. 
No entanto, o dinamismo e a imprevisibilidade dos processos de apropriação me surpreenderam. Em conversa com o dançarino Luiz César, registrei a seguinte declaração: "eu consigo fazer tudo na percussão, ou seja, a pessoa não está só escutando, a pessoa ta vendo a música ali" (NASCIMENTO, 2009). Assim, o que Vilela entende como "subordinação" à musicalidade é interpretado poeticamente como um meio de tornar visível o que é sentido a partir de estímulos sonoros; seria como "ver" a música.

Outro fator enfatizado pelos grupos em suas danças é o sincronismo, pois eles lidam com o referencial do palco com frente única, no modelo em que se apresentam as bandas de samba duro. Mesmo não dispondo de todo o aparato do palco italiano, a nova geração de dançarinos considera ultrapassado o outro formato. A organização do grupo não privilegia espaços circulares, como nos sambas de roda. A atenção à simetria visual é algo predominante na dança axé, interferindo nos posicionamentos espaciais, figurinos e movimentos. Com o sincronismo em dança, "a sensação de estar dançando junto também é vivenciada pelo dançarino como uma ampliação de seu próprio corpo. Ele se sente maior e mais forte com seu movimento vivido por vários corpos ao mesmo tempo" (VILELA, 1998, p. 125-126).

Assim, as organizações espaciais seguem configurações simétricas, como divisões em quadrados e retângulos, triângulo, linhas paralelas e formações em "V". Os movimentos também são simétricos, como braço alongado girando,

14. Passada a experiência do concurso de dança realizado no Liverpool, Nurred Tannous, proprietária da escola de dança Espaço do Corpo, deu início a uma série de atividades semestrais no espaço cênico do Teatro Rondon Pacheco, em Uberlândia. Denominada Academia Espaço do Corpo e Amigos do Axé, a série teve sua primeira edição em março de 2008. Cf.: Academia Espaço do Corpo e Amigos do Axé. Uberlândia, 2008, DVD. esticado e flexionado. Cabe ressaltar que as movimentações de quadris dificilmente atingem o grau de simetria dos braços, por exemplo. Todavia, "a gente procura muito o sincronismo, tanto pra poder apresentar é... tem o olhar também, o sorriso, sempre ta sorrindo pras pessoas e principalmente o sincronismo" (RAMOS, 2009). Assim, movimentos e formas de disposição espacial, nesses moldes, sugerem harmonia entre os grupos e o espaço. ${ }^{14}$

Contudo, essas codificações se acentuaram em meados de 2007, quando ocorreu um concurso de dança axé no clube Liverpool. Esse evento atingiu em cheio - e positivamente - as expectativas, os anseios e o modo de fazer dança axé em Uberlândia pelos populares. Segundo Luiz Nascimento, representou uma interessante descoberta,

porque até então eu não tinha visto grupo de axé, grupo de dança de axé (...) Até então eu não sabia que tinha tantos grupos de axé, eu achava que era poucos dançarinos, achava que ninguém dançava axé. Quando eu cheguei no Liverpool eu vi que era um outro mundo, eram muitos grupos de axé (NASCIMENTO, 2009).

Até a realização do concurso, que possibilitou o encontro de dançarinos de diferentes localidades, a prática da dança axé estava limitada aos espaços que cada grupo costumava frequentar, ensaiar e passear em seus bairros. Com novas informações captadas no decorrer do evento, os grupos deixaram de lado o que "aprenderam pela tele- 
visão, pelo youtube" (TANNOUS, 2009) e buscaram outros referenciais, como Swing Raça, Toa-Toa, Axé Moi, Cia. Portal do Axé, Trupe Dance, Swing do Bicho e Aero Brasília.

Isso aconteceu porque, no concurso, todos os grupos queriam sair vencedores, o que motivou os populares a encontrar meios outros que tornassem possível tal feito, pautandose na proposição de que, "se está querendo ser o melhor grupo de Uberlândia, tem que ser diferente" (FERREIRA, 2009). Uma das formas elaboradas para "ser diferente" foi inserir as famosas "aberturas", que nada mais eram senão a preparação do público para o axé, uma espécie de iniciação. Nessas aberturas, os grupos mesclam movimentações diversas, desde a dança de rua, passando pelas danças de salão e jazz, até o teatro.

Grosso modo, se antes dos concursos os grupos de dança axé "dançava igual um caminhãozinho de japonesinho, tudo igualzinho, o que eles viam ali no youtube, passou daquilo ali eles não davam seguimento" (TANNOus, 2009). Hoje a situação é diferente, "porque do jeito que ta aqui em Uberlândia pra você poder dançar mesmo esse axé você tem que ser um grupo bão mesmo pra chamar a atenção, senão não dá" (RAMOS, 2009).

A busca do aperfeiçoamento da dança encontrou no meio popular outros motivadores, como o lançamento do DVD solo do dançarino Mantena, em que ele aparece dançando em monumentos históricos de Salvador e em Uberlândia, no Centro de Eventos Acrópole, e a realização dos encontros Academia Espaço do Corpo e Amigos do Axé, no Teatro Rondon Pacheco - os grandes mediadores, atualmente, entre danças executadas em festas e trabalhos coreográficos com características cênicas, uma vez que dispõem da estrutura de um teatro ${ }^{15}$ com coxias, iluminação, rotunda, camarim e linóleo.

A primeira edição do encontro aconteceu nos dias 29 e 30 de março de 2008, com cerca de 12 grupos de samba duro se apresentando em cada dia. Promovido por Nurred Tannous, o evento já se encontra em sua quarta edição. Detalhe interessante é que essas apresentações são gravadas com uso de equipamentos audiovisuais, mas "não é competição. É só apresentação, só pra divulgação (...) é pra conseguir patrocinador". ${ }^{16} \mathrm{~A}$ inexistência do caráter competitivo nesses encontros, entretanto, não implica afirmar que ele esteja ausente no cotidiano dos dançarinos populares.
15. A cidade de Uberlândia dispõe apenas de um teatro em funcionamento, o Teatro Rondon Pacheco, com apenas 380 lugares. Visando atender à demanda local, a Prefeitura de Uberlândia conta com o uso compartilhado desse teatro desde 1995, pois o espaço pertence à Escola Estadual Bueno Brandão e "funciona, em média, 12 horas por dia, de domingo a sábado. $\mathrm{O}$ outro teatro que temos na cidade é o Grande Othelo que foi interditado em 1997, devido ao desmoronamento de uma parte do prédio". As atividades no Teatro Rondon Pacheco baseiam-se no "Termo de Convênio" estabelecido entre a Secretaria de Estado de Educação de Minas Gerais e a Prefeitura de Uberlândia, que autoriza a utilização "de forma compartilhada e gratuita do Teatro Rondon Pacheco". Em contrapartida, a Prefeitura se responsabiliza por administrar o teatro junto com a direção da Escola Estadual Bueno Brandão, utilizando seu pessoal especializado $e$ técnico, suporte administrativo e financeiro para sua manutenção e funcionamento, bem como "zelar pela guarda, conservação e manutenção do teatro". Os trechos mencionados acima se referem ao projeto enviado à Secretaria de Estado de Educação de Minas Gerais 
em junho de 2009 e assinado por Wladimir Rodrigues de Queiroz, diretor da Escola Estadual Bueno Brandão, e Mônica Debs Diniz, atual secretária de Cultura de Uberlândia. No entanto, quando a Secretaria Municipal de Cultura negocia com artistas da cidade a ocupação do mesmo teatro, via edital, é acrescentada uma série de impostos e taxas inexistentes no contrato com a Secretaria Estadual de Educação. Grosso modo, são repassados aos artistas uberlandenses, que não possuem outro teatro na cidade, os gastos e encargos relativos à manutenção e ao funcionamento do Teatro Rondon Pacheco. Para informações sobre os valores cobrados para uso do referido teatro, consultar o edital disponível em: <http://teatrorondonudi. blogspot.com/2009/11/ edital-de-ocupacao-fevereiro-abril-2009. html>. Acesso em: 05 jan. 2010. Também em: <http:// www.uberlandia.mg.gov. br/secretaria.php?id_ $c g=137 \& i d=10>$. Acesso em: 05 jan. 2010.

16. O uso do espaço cênico por grupos populares de dança axé começou a galgar outros degraus em 2009. Destaco, nesse cenário, a participação dos grupos Balança Axé, Pervertidos do Axé e Swing'art no Circuito
A dança axé na cidade de Uberlândia lida constantemente com a competição em diferentes níveis, embora os dançarinos de samba duro não tenham vivenciado os tempos de festivais competitivos. Antes de qualquer coisa, é uma prática corporal contemporânea, imersa em seu tempo, numa realidade em que jogos e disputas estão presentes ordinariamente. A competição já fazia parte do universo popular antes mesmo da prática corporal dançante, tendo por base o desempenho escolar, avaliado por boletins e notas, a realidade econômica individual e da família, a concorrência por uma boa vaga de emprego e o consumo e exposição social dos bens consumidos.

A competição no meio popular contemporâneo não é algo estanque; ao contrário, está fortemente imbricada nas relações sociais que nele de desenvolvem. Manifesta-se como "uma disputa entre os grupos" (NASCIMENTO, 2009), uns procurando superar os outros, ou mesmo disputas individuais, como relatou Luesley da Silva Azevedo (2009): "quando está numa festa, junta todo mundo, cada um quer tomar o espaço do outro, cada um quer 'quebrar' mais que o outro, tem gente que sai com o corpo até doendo; se alguém quer fazer mais que eu, eu 'arregaço'". Os comportamentos competitivos na dança axé geram intrigas, mas possuem como eixo a discussão deflagrada em torno da questão "quem é o melhor bailarino?" (NASCIMENTO, 2009).

O esforço despendido para "ser o melhor" e para "eleger o melhor" acompanha a busca de status na sociedade, isto é, a prática corporal em dança aparece como meio principal para que jovens e crianças conquistem visibilidade social. Nesse sentido, a dança cumpre importante papel social quando associada à possibilidade de os sujeitos transformarem suas realidades imediatas. O status atribuído aos dançarinos que se destacam, segundo os códigos por eles mesmos forjados, não se limita ao momento da apresentação. Essa condição acompanha os dançarinos em todos os momentos de suas vidas em suas comunidades: na escola, no trabalho formal, nas ruas e nas festas.

No entanto, esse desejo de inversão da realidade social via dança é expresso de diferentes maneiras, e não só pela competição declarada; ele aparece também na enunciação da palavra "sucesso" e na concepção do que é "ser famoso". Marcus Vinicius, do grupo Pirei Axé, por exemplo, enfatiza que, "antes, quando começou, porque tem muito grupo, a gente nem destacava não; agora nóis ta no auge, ta pegando fogo nas paradas de 
sucesso (...) agora a gente tá começando a ficar famoso" (NASClMENTO, 2009). O propósito de conseguir ser visto e notado por meio da dança só é alcançado a partir do domínio de códigos estabelecidos e partilhados pelos dançarinos: "famoso igual, tipo assim, se vai num show todo mundo te conhece, todo mundo fica te olhando" (TORRES, 2009). Ser famoso, nesse contexto, é ser visto.

Desse modo, o olhar um pouco mais atento e dirigido às práticas populares veiculadas nos meios de comunicação de massa e pela indústria cultural e às suas possibilidades de apropriação inviabiliza afirmações de que os consumidores submetem seus corpos, de que os meios

obrigam à reprodução de certos modelos, lembrando mais um bando de robôs (...) Todos dançam da mesma forma, como clones simbólicos de um momento de crise da identidade cultural (...) o povo continua de fora da dança, desconhecendo todas as possibilidades que a linguagem pode lhe oferecer (MELLO, 2003, p. 4 e 5).
Double - Música e Dança, realizado entre os dias 21 e 24 de maio de 2009 em Uberlândia e organizado pelo Setor de Dança da Secretaria Municipal de Cultura, bem como a aspiração à participação na XXI Edição do Festival de Dança do Triângulo, realizada pelo grupo Spaço Axé, que enviou a coreografia "Fusion" para o processo seletivo do evento, mas não conseguiu parecer favorável da comissão composta por Helena Bastos, Ernesto Gadelha e Rui Moreira.

A não compreensão sempre leva a avaliações apressadas e não condizentes à realidade vivenciada pelos sujeitos sociais. As pessoas não apenas dançam o axé; elas se organizam e se identificam por meio de grupos de axé. É claro que "tem aqueles que dançam porque é moda, tem uns que dançam porque é legal estar competindo, dança pelo figurino, você escuta tanta coisa, cara" (TORRES, 2009). E também "tem gente que tem o pensamento de que eu vou dançar axé e as mulheres vão me olhar e eu vou 'catar' mais mulher, entendeu?" (NASCIMENTO, 2009). Todos esses sentidos compõem motivos que levam crianças e jovens a praticar a dança axé em cidades do interior de Minas Gerais nesta primeira década do século XXI.

De todo modo, mesmo lidando com uma multiplicidade de significações, a dança popular axé suscita constantes leituras que não a compreendem. Richard Shusterman, filósofo americano, dedica-se a analisar expressões artísticas das artes populares da mídia. Para tanto, o autor privilegia a análise estética como instrumento para compreensão e legitimação da arte popular, ancorado nos métodos e ensinamentos da filosofia pragmatista. Ele declara:

Os prazeres legítimos da arte erudita tornaram-se muito ascéticos e etéreos para a maioria das pessoas, ao passo que as formas expressivas que nos oferecem um prazer mais intenso são normalmente desclassificadas como mero divertimento (...) Em termos mais gerais, o julgamento estético não é a pura, elevada e desinteressada contemplação da forma, tal como é normalmente definido. Ele é, ao contrário, profundamente condicionado e governado por interesses e preconceitos político-sociais (inclusive raciais) (...) verdade e status artístico são assim, em grande parte, uma questão de controle político-social (SHUSTERMAN, 1998, p. 45 e 178). 
Mesmo lidando com todo esse complexo e conturbado jogo de valores em sociedade, em ambientes periféricos a prática da dança aparece também como oportunidade, como alternativa ou mesmo como fonte disseminadora de elementos culturais e estéticos.

Devemos sempre ter em vista que no meio popular, como muito bem destacou Vilela (1998, p. 201), "a maneira de [os sujeitos] se posicionarem enquanto indivíduos e se tornarem visíveis à sociedade se faz pelo corpo e pela dança". Não se trata de simplificar o processo, com o argumento de que "enquanto atividade dispersa dentro da cultura dominante, a dança popular se vê como conformismo ou como resistência" (KATZ, 1989, p. 11), mas sim de perceber as elaborações feitas pelos populares. Eles não só optam entre se conformar ou resistir, apesar de o fazer constantemente, mas descobrem e escoIhem meios de criar outras e diversificadas formas de fazer. Por meio do samba duro, os populares transformam corpo físico em corpo social.

\section{REFERÊNCIAS BIBLIOGRÁFICAS}

ADORNO, Theodor W. Prologo a la television. In: Intervenciones: nueve modelos de critica. Caracas: Monte Ávila Editores C.A., 1969, p. 63-74.

ARAÚJO, Lília. Pagode da Bahia, Swing do Brasil! Disponível em: <http://www.sambando. com/swingueira16.html>. Acesso em: 09 jun. 2009.

AZEVEDO, Luesley da Silva Azevedo. Entrevista ao autor. Uberlândia, 30 jan. 2009.

BAKHTIN, Mikhail. A cultura popular na ldade Média: o contexto de François Rabelais. 2. ed. São Paulo/Brasília: Hucitec/Ed. da UNB, 1993.

BAUMAN, Zygmnt. Europa: uma aventura inacabada. (Trad. Carlos Alberto Medeiros). Rio de Janeiro: Jorge Zahar Ed., 2006.

BIÃO, Armindo. O obsceno em cena, ou o Tcham na boquinha da garrafa. Repertório Teatro \& Dança, v. 1, n. 1, 1998, p. 23-26.

CERTEAU, Michel de. Histórias de corpos. (entrevista). Projeto História. n. 25, dez. 2002. São Paulo: Educ, 20002, p. 407-412.

DIÓGENES, Glória. Cartografias da cultura e da violência: gangues, galeras e o movimento hip hop. São Paulo: Annablume, 2001.

ESSINGER, Sílvio. Axé music: o carnaval de Salvador embala o país. Disponível em: <http:// cliquemusic.uol.com.br/materias/ver/axe-music>. Acesso em: 23 dez. 2008.

FERREIRA, Thaline Alves. Entrevista ao autor. Uberlândia, 30 jan. 2009.

GÓMEZ, Zandra Pedraza. Corpo, pessoa e ordem social. (Trad. Simone Andréa Carvalho da Silva). Projeto História. n. 25, São Paulo, dez. 2002, p. 81-98.

GUARATO, Rafael. Dança de rua: corpos para além do movimento. Uberlândia: Edufu, 2008.

KATZ, Helena. A diferença entre arte e cultura. Jornal Urbano. São Paulo, 22 abr. 2009, p.3.

Danças populares brasileiras. São Paulo: Rhodia, 1989.

MARTÍN-BARBERO, Jesús. Dos meios às mediações: comunicação, cultura e hegemonia. 2. ed. Rio de Janeiro: UFRJ, 2003. 
MELO, Victor Andrade de; FERREIRA, Patrícia Gomes; SOUZA, Maria Inês Galvão. Dança e animação cultural: improvisações. Pensar a Prática - revista da Pós-graduação em Educação Física da Universidade Federal de Goiás, v. 6, 2003, p. 4 e 5. Disponível em: <revistas.ufg.br/index.php/fef/article/viewArticle/60>. Acesso em: 02 jan. 2009.

MIZRAHI, Mylene. Figurino funk: uma etnografia dos elementos estéticos de uma festa carioca. In: LEITÃO, Débora Krischk; LIMA, Diana Nogueira de Oliveira; MACHADO, Rosana Pinheiro (Orgs.). Antropologia e consumo: diálogos entre Brasil e Argentina. Porto Alegre: AGE Editora, 2006, p. 201-211.

NASCIMENTO, Luiz César Dias. Entrevista ao autor. Uberlândia, 05 maio 2009.

NAZARO, Thamires Braga. Entrevista ao autor. Uberlândia, 30 jan. 2009.

OLIVEIRA, Vitor Hugo de. Apud SILVA, Emilene. Samba da páscoa. Correio. Uberlândia. 02 abr, 1999, p. 18.

RAMOS, Gilmar da Silva (Chumbim). Entrevista ao autor. Uberlândia, 06 jul. 2009.

SHUSTERMAN, Richard. Vivendo a arte: o pensamento pragmatista e a estética popular. Trad. Gisela Domschke. São Paulo: Editora 34, 1998.

SILVA, Rafael Cordeiro. Cultura, dominação e emancipação: dois pontos de vista. InterAções: cultura e comunidade - Revista de Ciências da Religião da Faculdade Católica de Uberlândia. Uberlândia, v. 1, n. 1, 2006, p. 23-38.

SOUZA, Maria Inês Galvão. Arte, cultura e sociedade: uma rede intrigante para algumas reflexões sobre a dança. VIII Encontro Fluminense de Educação Física Escolar - Enfefe. Niterói: Universidade Federal Fluminense, 2004, p. 5. Disponível em: <grupoanima. org/arte-cultura-e-sociedade-uma-rede-intrigante-para-algumas-reflexoes-sobre-adanca/>. Acesso em: 10 mai. 2008.

STRAZZACAPPA, Márcia. A educação e a fábrica de corpos: a dança na escola. Cadernos Cedes. Ano XXI, n. 53, abr. 2001, p. 69-83.

TANNOUS, Nurred. Entrevista ao autor. Uberlândia, 05 mai. 2009.

TORRES, Fábio (Mantena). Entrevista ao autor. Uberlândia, 29 dez. 2008.

VILELA, Lilian Freitas. $O$ corpo que dança: os jovens e as tribos urbanas. Dissertação (Mestrado) - Faculdade de Educação Física, Universidade Estadual de Campinas, Campinas, SP, 1998.

VIRGÍNIA, Rosa. Mas o que é o pagodão? Disponível em: <www.negrabahia.com.br/mat_ ver.asp?ID=85>. Acesso em: 03 mai. 2007.

WILLIAMS, Raymond. Cultura e sociedade - 1780-1950. São Paulo: Companhia Editora Nacional, 1969.

Rafael Guarato é mestre em história, professor do Departamento de História da UNICENTRO-PR e pesquisador vinculado ao Populis-UFU (Núcleo de Pesquisa em Cultura Popular, Imagem e Som). 